\title{
Erratum to: Ignoring critique, attacking the critic
}

\section{O. S. Miettinen}

Published online: 8 April 2010

(C) Springer Science+Business Media B.V. 2010

Erratum to: Eur J Epidemiol (2010) 25:149

DOI 10.1007/s10654-010-9425-9

Unfortunately, under the section "References" the reference (1) has been incorrect in the print and online versions of this article. It is presented correctly here.

\section{Reference}

1. Miettinen OS. Book review. M Porta, S Greenland, JM Last (eds.). A Dictionary of Epidemiology. A Handbook Sponsored by the I. E. A. Eur J Epidemiol 2008; 23:813-7.

The online version of the original article can be found under doi:10.1007/s10654-010-9425-9. 